\title{
Analytic Hierarchy Process (AHP) as an Assessment Approach for Architectural Design: Case Study of Architectural Design Studio
}

Timuçin Harputlugil ${ }^{*}$

\section{Abstract}

Architectural design is complex and can be defined as an effective decision-making activity based on problem solving. This complexity is not based on content and volume of problems, but also heterogeneity and uncertainty of information provided for assessment, subjective approaches, and a large number of the criterion for assessment. The aim of this research paper is to contribute to the researches for assessment of architectural design by providing a novel approach based on Analytic Hierarchy Process (AHP) - a Multi Criteria Decision Making (MCDM) method. The approach supports an effective comparative analysis among the alternative projects based on determined criterion. The methodology is implemented with a case study in one of the design studios of Department of Architecture of Çankaya University on final design projects of a group of students with observation, research and assessment. The data used in the assessment is collected through interviews and surveys which is analysed by the help of a software. Based on the outcomes of the AHP-based approach, it has been seen that this approach can provide numerical results that are comparable, measurable, gradable, consistent and can be reported separately for
Keywords: Architectural education, Analytic Hierarchy Process (AHP), Assessment of architectural design

*Asst. Prof. Dr. Department of Architecture, Faculty of Architecture, Çankaya University , Ankara, Turkey.

E-mail: tharputlugil@cankaya.edu.tr Orcid ID: http://orcid.org/0000-0002-30476531 
each assessor. However, it has also been found that the AHP-based method is suitable for evaluating only a limited number of projects. With the research, and by setting thresholds levels for evaluation, it has become clear that successful and unsuccessful projects can be separated for achievement and competence. Consequently, it has been observed that the approach has considerable potentials to be further developed to evaluate architectural projects comparatively, especially for architectural students' projects, and other architectural projects such as architectural design competitions.

\section{INTRODUCTION}

Design is the basic activity of architecture (Simon, 1969) and is based on problem solving and decision making (Davis, 2017). Simon (1969) identified design problems as sick problems since more problems are created for solution. In this context, architectural design is an iterative process based on feedbacks (Harputlugil et al., 2014) and it differs from many other design disciplines by the way it solves the problems and problems it contains. Dickson (2004) defines design and construction processes as the set of decisions required for the building process while Sebastian (2007) defines the process as analysis through synthesis.

Each architectural piece/product is unique when the program of requirements, site of the construction, stakeholders are considered. For this reason, no design is like any other and the final product is unique. Accordingly, the evaluation of the design process is complex and difficult. This involves the evaluation of architectural design for which each case is based, to choose the most appropriate one from among the other alternatives, and to rank alternative projects as well as accordingly define the pros and cons of the projects and to design them separately. Architectural design can include different criteria that can be defined according to the characteristics of each project, as well as universal evaluation criteria. Architectural design with this point of view; can be regarded as a set of possible solutions proposed for specific design problems and is aimed at achieving the desired level of design outcomes in the framework of the prescribed criteria. In this context, it is necessary to develop different methods for the evaluation of project alternatives designed for different people or groups, both in education and in professional practice.

Evaluation is an inevitable process for the product of design. The evaluation methodology is important as well as the content, context and the process. Çıkış and Çil (2009) describe evaluation process of architectural design in education as a measure of development, and point out evaluation criteria as the most 
important feature of evaluation. Hickman (2007) suggests that evaluation should be able to demonstrate the strengths and weaknesses of the project as well as the development of practical skills, technical knowledge, and research competence. Williams et al. (2010) emphasizes the importance of useful feedback to evaluation.

Design studios that constitute the spine of architectural education (Nazidizaji et al., 2014) are defined by Çıkış and Çil (2009) as practical working areas where design is evaluated and vocational education is integrated with art. Kalaycı (2016) states for the comparative evaluation in the design studios, which is a process of learning and teaching activities in groups, that it is inevitable for themselves and others to compete each other, and that it is a right of the student to know the concrete, non-subjective consequences of the explanatory, reasoned, specified criteria of the evaluation. In this context, it is also expected that the scope and criteria of the evaluation method is well defined as well as its transparent.

Critical numerical (quantitative) evaluation is now widely used in architectural education, however, it is not easy to quantify the results of subjective evaluations of different groups of people with common numerical values. In this context, it is possible to come across the work carried out on behalf of the development of numerical evaluation. Hassanpour and Ani (2015) and Utaberta et al. (2013) have developed recommendations for the development of numerical evaluation systems and the creation of feedback information to promote the project as far as possible. Alagbe et al. (2015) suggest that correctness, reliability, usefulness, and consistency for evaluation must be fundamental concepts, while Crooks et al. (1996) states that an accurate assessment improves the individual development and the education system. Webster (2006) believes that evaluation should be able to determine how far the goal of the specified learning outcomes has been achieved.

Traditional evaluation methods in architecture are limited with the defining of criteria and sub-criteria for evaluation, common language development in group evaluation processes, benchmarking, and definition of success threshold levels, etc. It is believed that various decision support systems can be used to overcome with these limitations. Multi Criteria Decision Making (MCDM) Methods, the best-known decision support system (Triantaphyllou, 2000), are analytic methods (Timor, 2011) that involve many people in decision-making processes and allows for the evaluation of measurable and non-measurable factors that enable decisions to be taken in line with goals (Özcan et al., 2011) . 
MCDM systems are based on the evaluation and numerical comparison of alternatives within the framework of the defined criterion. The main problems experienced in traditional architectural design evaluations may already be identified as, the relative superiority and inferiority of project alternatives relative to each other, and the absence of numerical data for comparative analysis. Considering all the previously mentioned evaluation conditions; the assessment of architectural design is prone to individual and group evaluations that are particularly subjective, with concrete criteria that cannot be assessed in the same measurement units. Since it requires accurate, reliable, consistent, and transparent evaluation methods based on feedback, it is believed that that using MCDM methods for this purpose (as an evaluation tool), that there is an enormous potential if properly implemented. In this context, and within this research, the potentials of evaluation of architectural design based on Analytic Hierarchy Process (AHP) (a MCDM Methodology used broadly) are scrutinized. Following this introduction is a literature review. The approach is narrated with details in the chapter titled material method and followed by a case study told in details in. Discussion of the outcomes of the research is followed by conclusion chapter.

\section{LITERATURE REVIEW}

Analytic Hierarchy Process (AHP), Analytic Network Process (ANP), Preference Ranking Organization Method for Enrichment Evaluations (PROMETHEE), Simple Additive Weighting (SAW), Weighted Product Method (WPM), Technique for Order Preference by Similarity to Ideal Solution (TOPSIS), Elimination and Choice Expressing Reality (ELECTRE), dominance, max-max, max-min, are the most used MCDM methodologies and can be classified as below (Riberio et al., 2011) (Figure 1).

Figure 1. MCDM Taxonomy adapted from Riberio et al. (2011)

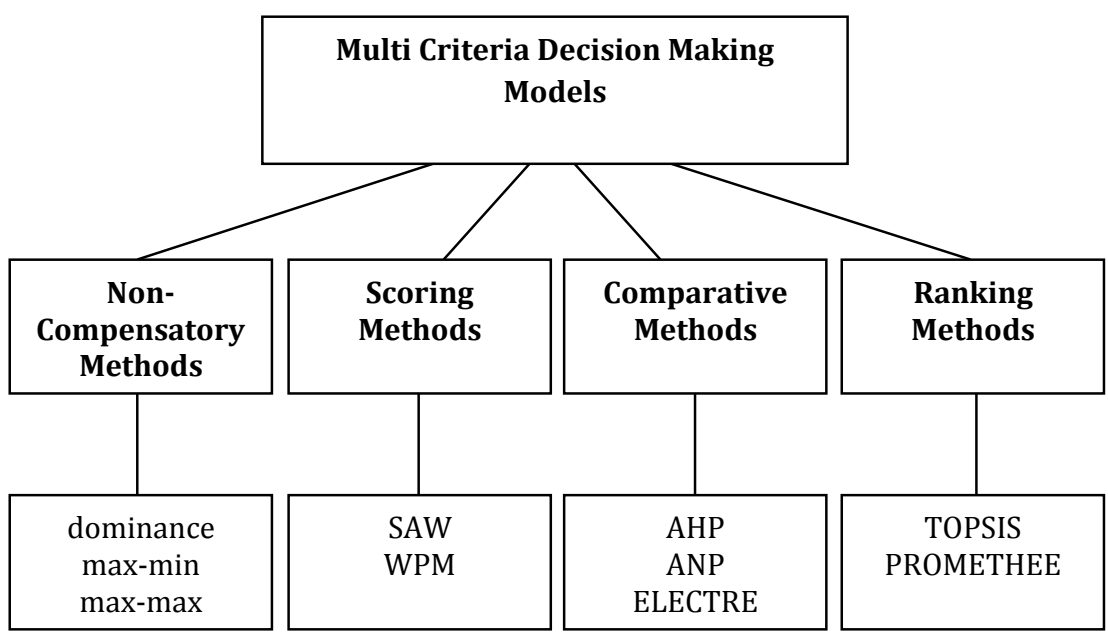


It is possible to come across research that evaluates the use of MCDM methods for different processes of building. In the study of Mela et al. (2012), different building designs were assessed with different MCDM methods in the context of different criteria, Heravi et al. (2017) have shown that they use MCDM methodologies for the optimization of sustainable industrial plant selection for petrochemical projects. Si et al. (2016) used MCDM methodologies to integrate green technologies into the building, while Mulliner et al. (2016) compared MCDM methodologies in a comparative manner for the calculation of sustainable housing costs. In addition to these, it can be seen, that different MCDM methodologies are used in other topics, such as, material (Akadiri et al., 2013) and construction method selection (Tsai et al., 2013). According to the evaluation based on 88 studies made by Espino et al. (2014) which is one of the most widely circulated publications in this context, MCDM methods in the construction sector are used for tender, construction and structure, geotechnics, materials, equipment, project management, highways, settlement planning, waste management and water management. They found that AHP is the most commonly used method of study in which 25 different methods are used.

Considering the above classification, AHP with its widespread use in MCDM applications; it can be observed that the comparative matrices are acceptable (Harputlugil et al., 2011) , the length of the evaluation periods is not long enough, the ease with which the abstract and the concrete criteria can be evaluated together, the consistency analysis can be performed, the criteria and subcriteria hierarchy can be defined, the results are clear, understandable and straightforward, and that effective decisionmaking in complex situations is possible (Harputlugil et al., 2014) compared to the other methods (Timor, 2011). Considering the above-mentioned classification, AHP with its widespread use in MCDM applications emerges from other methods (Timor, 2017) with the following distinctives such as: using pairwise comparative matrixes, easiness of operation, evaluation of tangible and intangible criteria all together (Aksakal \& Dağdeviren, 2015), ability for measurement of consistency, structuring hierarchy of main criteria and sub criteria, eventbased easy adaptation of criterion, acceptable number of matrixes for evaluation (Harputlugil et al., 2011). Besides clear results, which are understandable and straightforward, it also makes it possible to make effective decision-making in complex situations. In addition to all these reasons, the AHP's ability to provide adaptability, widespread use (Gandhi et al., 2015) for different disciplines with different areas and purposes and the ability to present complex expert assessment analysis in a simple and 
understandable manner can be listed as surplus values for the potential of architectural design evaluation (Omkarprasad \& Sushil, 2006).

The widespread use of AHP in social and many engineering disciplines such as, construction and building process, is striking. On the other hand, its use for a subjective assessment of tangible and intangible criteria such as architectural design is very limited. In this respect, an AHP-based approach has been developed for the evaluation of architectural design based on these considerations.

AHP is one of the multi-criteria decision-making methods developed by Saaty (1980). The AHP has been used in many fields due to its plain and simple mathematical system based on pairwise comparison which includes tangible and intangible criterion for numerical evaluation. The AHP allows for alternatives to be evaluated in terms of decision-makers, within the framework of determined main and sub-criteria, to solve the problems that can be hierarchically structured for the specified target (Saaty, 1990). In addition to its ease of use, the ability to evaluate consistency check provides results that are close to true scores (Triantaphyllou \& Mann, 1995). The AHP structures the problem in a hierarchical structure when the alternatives to be selected by the decision maker/s, criterion and sub-criterion, are listed for the specified purpose. Based on this structure, comparison matrixes are formed. The resulting matrix is transformed into the priority vector. The consistency rate is then calculated (Timor, 2011).

Questions for pairwise comparisons should be expressed clearly. Sub-criteria are arranged in order of priority relative to their values. Pairwise comparison judgments are placed in vertical and horizontal columns in the decision matrix. The evaluation scales on the table proposed for pairwise comparisons are between the numbers 1-9 where two measures are equally important, 1 is used, while numbers 3-5-7-9 represent increasing importance. Numbers 2-4-6-8 are also used for intermediate evaluations. The digits used are not used as numerical values but are used to define the significance levels of the metrics relative to each other in pairwise comparisons (Saaty, 1980; Saaty, 1990; Adamovic et al., 2008) (Table 1, Table 2). 
Analytic Hierarchy Process (AHP) as an Assessment Approach for Architectural Design: Case Study of Architectural Design Studio

Table 1. Definitions of pairwise comparison numerical scales (Saaty, 1980; Saaty, 1990; Adamovic et al., 2008)

\begin{tabular}{|l|l|}
\hline $\begin{array}{l}\text { Values } \\
\left(i_{\mathrm{a} j \mathrm{~b}} ; k_{\mathrm{c}} l_{\mathrm{d}}\right)\end{array}$ & Explanation \\
\hline 1 & Criteria $i$ and Criteria $j$ are of equal importance \\
\hline 3 & Criteria $i$ is weakly more important than Criteria $j$ \\
\hline 5 & Criteria $i$ is strongly more important than Criteria $j$ \\
\hline 7 & Criteria $i$ is very strongly more important than Criteria $j$ \\
\hline 9 & Criteria $i$ is absolutely more important than Criteria $j$ \\
\hline $2,4,6,8$ & Intermediate Values \\
\hline $\mathrm{a}, \mathrm{b}=(1,2,3, \ldots . ., \mathrm{n}=$ number of criteria) \\
$\mathrm{c}, \mathrm{d}=(1,2,3, \ldots . ., \mathrm{n}=$ number of alternatives $)$
\end{tabular}

At a specified level of hierarchy, when the number of criteria is $n$, the number of alternatives is $\mathrm{m}$; $\mathrm{n}$ number of matrices consists of $\mathrm{m}$ horizontal and vertical cells (Table 3 ).

Table 2. Definitions of pairwise comparison numerical scales of main and sub criterion (Adamovic et al., 2008)

\begin{tabular}{|c|c|c|c|c|c|c|}
\hline$\rangle^{i}$ & $\begin{array}{l}\text { Criteria } \\
1\end{array}$ & $\begin{array}{l}\text { Criteria } \\
2\end{array}$ & $\begin{array}{l}\text { Criteria } \\
3\end{array}$ & $\begin{array}{l}\text { Criteria } \\
4\end{array}$ & ...... & $\begin{array}{l}\text { Criteria } \\
\mathrm{n}\end{array}$ \\
\hline $\begin{array}{l}\text { Criteria } \\
1\end{array}$ & 1 & $\mathrm{i}_{1} \mathrm{j}_{2}$ & $\mathrm{i}_{1} \mathrm{j}_{3}$ & $\mathrm{i}_{1} \mathrm{j}_{4}$ & $\ldots$ & $\mathrm{i}_{1} \mathrm{j}_{\mathrm{n}}$ \\
\hline $\begin{array}{l}\text { Criteria } \\
2\end{array}$ & $\mathrm{i}_{2} \mathrm{j}_{1}$ & 1 & $\mathbf{i}_{2} \mathbf{j}_{3}$ & $\mathrm{i}_{2} \mathrm{j}_{4}$ & $\ldots$ & $i_{2} j_{n}$ \\
\hline $\begin{array}{l}\text { Criteria } \\
3\end{array}$ & $i_{3} j_{1}$ & $\mathbf{i}_{3} \mathbf{j}_{2}$ & 1 & $\mathbf{i}_{3} \mathrm{j}_{4}$ & $\ldots$ & i3jn \\
\hline $\begin{array}{l}\text { Criteria } \\
4\end{array}$ & $\mathbf{i}_{4} j_{1}$ & $\mathrm{i}_{4} \mathrm{j}_{2}$ & $\mathbf{i}_{4} \mathbf{j}_{3}$ & 1 & $\ldots$ & $i_{4} j_{n}$ \\
\hline$\ldots \ldots$ & $\ldots$ & $\ldots$ & $\ldots$ & $\ldots$ & $\ldots$ & $\ldots$ \\
\hline $\begin{array}{l}\text { Criteria } \\
\mathrm{n}\end{array}$ & $\mathrm{in}_{\mathrm{n}} \mathrm{j}_{1}$ & $\mathrm{in}_{\mathrm{n} 2}$ & $\mathrm{i}_{\mathrm{n} j 3}$ & $i_{n j} 4$ & $\ldots$ & $i_{n} j_{n}=1$ \\
\hline $\mathrm{i}_{\mathrm{a} j \mathrm{j}} \mathrm{b}:(\mathrm{a}$ & & Vo & able 1) & & & \\
\hline
\end{tabular}


Table 3. Definitions of choosing alternatives based on priorities of criterion (Adamovic et al., 2008)

\begin{tabular}{|c|c|c|c|c|c|c|}
\hline \multicolumn{7}{|c|}{ Criteria i $\quad(\mathrm{i} \quad \rightarrow 1,2, \ldots ., \mathrm{n})$} \\
\hline & $\begin{array}{l}\text { Alternative } \\
1\end{array}$ & $\begin{array}{l}\text { Alternative } \\
2\end{array}$ & $\begin{array}{l}\text { Alternative } \\
3\end{array}$ & $\begin{array}{l}\text { Alternative } \\
4\end{array}$ & $\cdots$ & $\begin{array}{l}\text { Alternative } \\
\mathrm{m}\end{array}$ \\
\hline $\begin{array}{l}\text { Criteria } \\
1\end{array}$ & 1 & $\mathrm{k}_{1} \mathrm{l}_{2}$ & $\mathrm{k}_{1} \mathrm{l}_{3}$ & $\mathrm{k}_{1} \mathrm{l}_{4}$ & $\ldots$ & $\mathrm{k}_{1} \mathrm{l}_{\mathrm{n}}$ \\
\hline $\begin{array}{l}\text { Criteria } \\
2\end{array}$ & $\mathrm{k}_{2} \mathrm{l}_{1}$ & 1 & $\mathrm{k}_{2} \mathrm{l}_{3}$ & $\mathrm{k}_{2} \mathrm{l}_{4}$ & $\ldots$ & $\mathrm{k}_{2} \mathrm{l}_{\mathrm{n}}$ \\
\hline $\begin{array}{l}\text { Criteria } \\
3\end{array}$ & $\mathrm{k}_{3} \mathrm{l}_{1}$ & $\mathrm{k}_{3} \mathrm{l}_{2}$ & 1 & $\mathrm{k}_{3} \mathrm{l}_{4}$ & $\ldots$ & $\mathrm{k}_{3} \mathrm{l}_{\mathrm{n}}$ \\
\hline $\begin{array}{l}\text { Criteria } \\
4\end{array}$ & $\mathrm{k}_{4} \mathrm{l}_{1}$ & $\mathrm{k}_{4} \mathrm{l}_{2}$ & $\mathrm{k}_{4} \mathrm{l}_{3}$ & 1 & $\ldots$ & $\mathrm{k}_{4} \mathrm{l}_{\mathrm{n}}$ \\
\hline “"' & $\cdots$ & $\ldots$ & $\ldots$ & ... & $\cdots$ & $\cdots$ \\
\hline $\begin{array}{l}\text { Criteria } \\
\mathrm{n}\end{array}$ & $\mathrm{k}_{\mathrm{n}} \mathrm{l}_{1}$ & $\mathrm{k}_{\mathrm{n}} \mathrm{l}_{2}$ & $\mathrm{k}_{\mathrm{n}} \mathrm{l}_{3}$ & $\mathrm{k}_{\mathrm{n}} \mathrm{l}_{4}$ & $\ldots$ & $\mathrm{k}_{\mathrm{n}} \mathrm{l}_{\mathrm{n}}=1$ \\
\hline
\end{tabular}

All pairwise comparison matrices basically have two features: The diagonal values in each matrix are equal to 1 and all matrix values are reciprocal (iajb $=1 / \mathrm{ibja} ; \mathrm{kcld}=1 / \mathrm{kdlc}$ ). The eigenvector $\mathrm{w}$ of matrix $A$ is formulated as the formula $A w=\lambda \max w$. When the vector $w$ is normalized, it becomes the vector of criteria priorities with respect to the goal. $\lambda \max$ is the largest eigenvalue of the matrix $\mathrm{A}$ and the corresponding eigenvector $\mathrm{w}$ contains only positive entries. Accordingly, the consistency is defined as CR (consistency ratio) $=\mathrm{CI}$ (consistency index) / RI (random index) equality. For RI (random index) random index table is used (Table 4). $\mathrm{CI}=\lambda \max -\mathrm{n} / \mathrm{n}-1$ must be used for the consistency ratio. If the CR value is less than 0,10 the evaluation is considered to be consistent. If the consistency ratio is greater than 0,10 pairwise comparisons should be reviewed (Saaty, 1980; Saaty, 1990; Adamovic et al., 2008; Timor, 2011).

Table 4. Random index table

\begin{tabular}{|l|c|c|c|c|c|c|c|c|c|c|}
\hline $\begin{array}{l}\text { Matrix } \\
\text { size }\end{array}$ & 1 & 2 & 3 & 4 & 5 & 6 & 7 & 8 & 9 & 10 \\
\hline $\begin{array}{l}\text { Random } \\
\text { Index }\end{array}$ & 0 & 0 & 0,52 & 0,89 & 1,11 & 1,25 & 1,35 & 1,40 & 1,45 & 1,49 \\
\hline
\end{tabular}


AHP has four axioms namely, Reciprocal Judgments, Homogeneous Elements, Synthesis and Expectations (Saaty, 1986). The reciprocal axiom is used to construct the comparison matrices. According to this axiom, the knowing of the comparison matrix defines the corresponding comparison matrix. The Homogeneous Elements axiom conveys the evaluation of the factors to be evaluated with a preferred scale. Furthermore, a criterion cannot be considered infinitely good or bad in comparison to another. The third axiom, Synthesis states that the criteria are independent of each other and states that the elements in a hierarchy do not depend on lower level elements. The last axiom, Expectation, indicates that a problem can be presented in a hierarchical structure to be evaluated, and that each criterion and alternate that affects the decision problem should be included in the hierarchy (Timor, 2011; Saaty, 1986; Kuruüzüm \& Atsan, 2001). Consequently, the AHP has stages of defining the problem, ordering decision criteria, creating a hierarchical structure, forming pairwise comparison matrices, calculating the priority vectors of the matrices, and measuring the consistency along with combining weights (Saaty, 1994).

\section{MATERIAL AND METHOD}

It can be observed in the important indexes surveyed, that there are only a limited number of publications of usage of AHP in the architectural field which comparatively evaluate architectural design projects. One of the publications noted, proposes a fuzzy decision-making model for choosing the best project for a pavilion design by Palabıyık and Çolakoğlu (2012). Harputlugil et al. (2011) used AHP for design quality approach while Bitarafan et al.(2015) used the methodology for another purpose of selecting the optimal composition of architectural forms. Arroyo et al. (2015) also used AHP as one of the methodologies for resolving the problem of choice in detailed design. Nevertheless, usage of AHP for different purposes of building process such as, assessment of sustainability in buildings (Markelj et al., 2014), budget estimation (Lai et al., 2008), project management (AlHarbi, 2001), identification of the importance of urban renewal project criteria (Lee \& Chan, 2008), comparison of green building assessment tools (Ali \& Al, 2009), planning risk during project planning and security risk analysis in budgetary processes (Aminbakhsh, 2013) available land for buildings (Pandav et al., 2016) and location selection (Nahid \& Gholam, 2010) can also be found in the literature.

Within the scope of this study, the proposed AHP-based approach was carried out by taking four students work done in Veral \& Veral + Sepkin studio, which is one of the four vertical studios of 
Çankaya University Architecture Department's 2014-2015 spring term graduation projects. Within the scope of this research, evaluators (decision makers) who had participated in the AHP evaluation system are the studio tutors(academicians) who have long and qualified professional experience. In addition to running design studios in architecture schools, they have won awards in countless architectural competitions and have been jury members for several competitions. Within this context, it is believed that, their competence to evaluate architectural design projects required for this research is at high level. Assessment criteria and sub-criteria were determined by the studio tutors after transferring information to them and guiding them through assessment process. Specified criteria and sub-criteria were organized in the AHP hierarchy and the evaluation study was conducted with Expert Choice 11.5 academic version software. Expert Choice software for AHP evaluation was used based on several advantages such as; allowing non-experts to easily evaluate, intuitive graphical user interface, simultaneous automatic calculation of priorities, simultaneous consistency control and sensitivity analysis (Alessio \& Ashraf, 2009). Including the preceding, graphically reporting numerical data and the process steps associated with it was also one of the reasons for using the software. Studio tutors are primarily asked to evaluate the projects based on the traditional system. The rankings of the student projects were recorded according to the numerical grades given in the evaluation made as a group with the traditional system. In the AHP-based assessment approach, the studio tutors were asked to evaluate the projects individually and the consistency check was done through the software used in the evaluation process. The resulting individual and group results were shared with the studio tutors and compared with the traditional evaluation results, the differences between both systems comprehensively analysed, and the positive and negative aspects of the AHP based approach were investigated. The implementation steps of the approach are shown in Figure 2. 


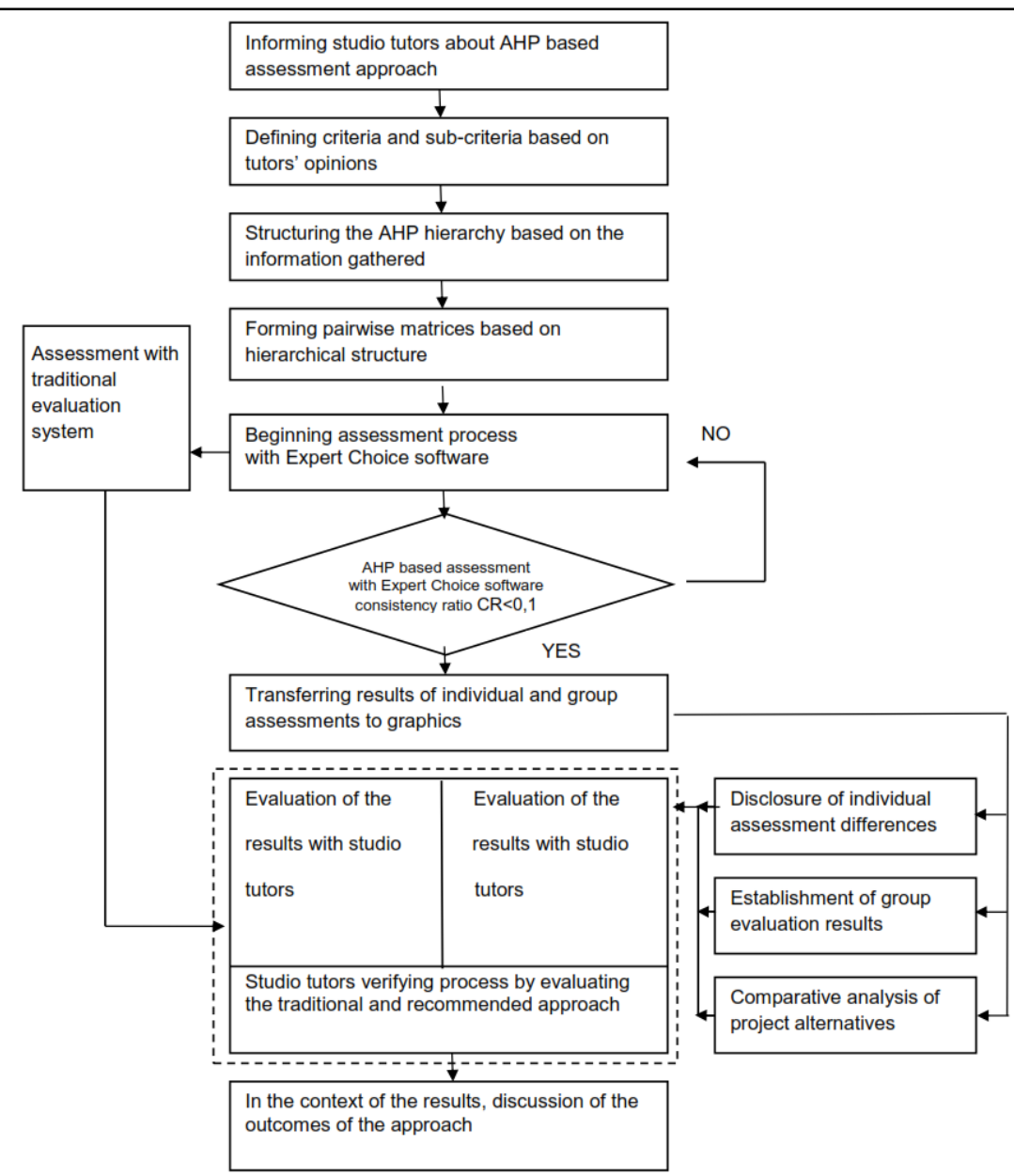

\section{CASE STUDY}

This research aims to investigate alternatives to the traditional assessment methods in architecture. With this research the topics below are researched based on the outcomes of the case study: i) comparative evaluation of student projects, ii) definition of scholars' evaluation criteria and their priorities, iii) setting out individual and group assessment priorities of scholars, iv) determining the positive or negative sides of student projects relative to other projects, v) possibility to carry out what if analyses.

\section{Structuring}

The criterion used in the case study can be formulated based on 3 main principles.

- Based on studio tutor's opinions

- Based on building typology and site conditions

- Based on the expectations of outcomes of the design studio

A culture and congress center design was decided as topic of the design project located in the new campus area of Çankaya
Figure 2. Implementation steps of the approach 
University beside Ankara-Eskișehir road on 30th $\mathrm{km}$. Within the scope of this design project students were evaluated based on the project submission of a $1 / 500$ site plan, $1 / 200$ scale architectural drawings(plans-sections-elevations), 3-dimensional perspectives and $1 / 200$ scale physical model that they delivered for the final project. Student project submissions were randomly numbered as A1-A2-A3-A4 for objectivity of the research. All the drawings and images of each project were presented to the studio tutors individually for their evaluation (Figure 3).
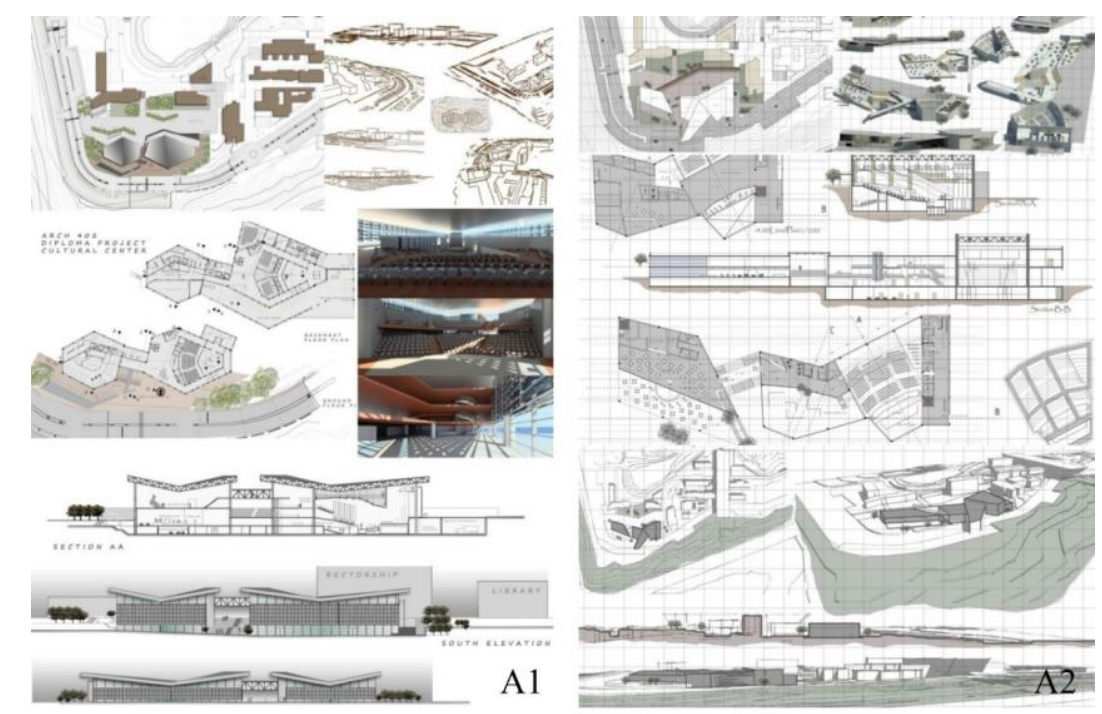

Figure 3. Student projects $\mathrm{A} 1, \mathrm{~A} 2$,
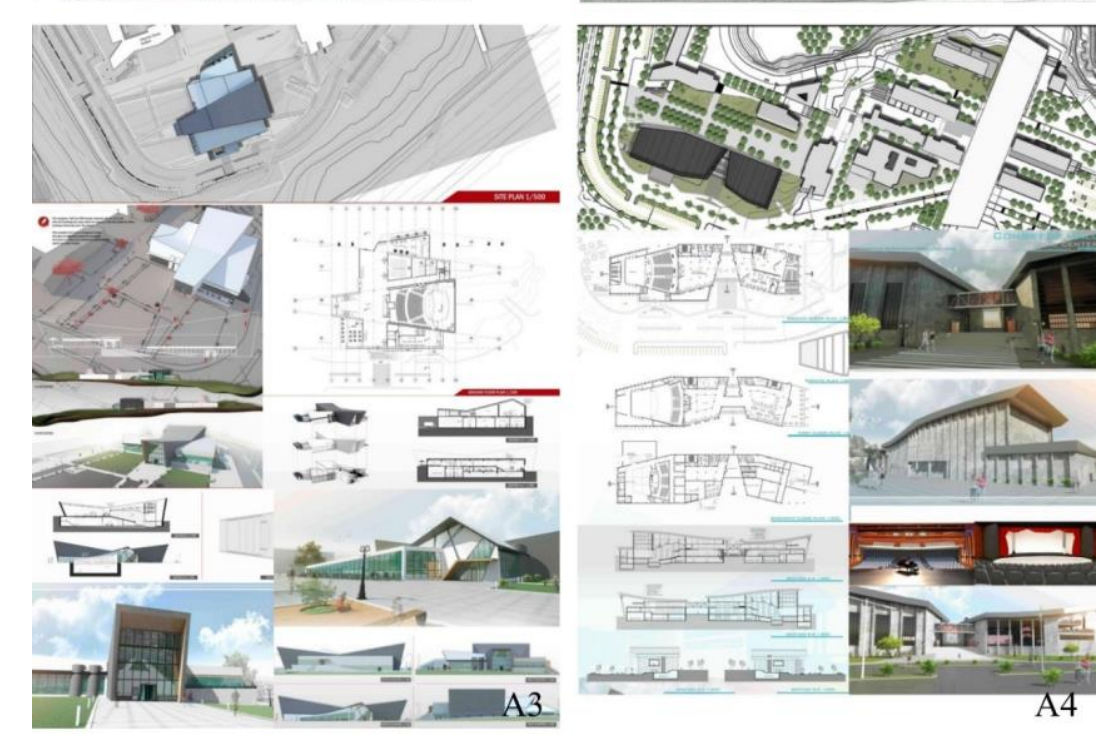

The main criteria of Functionality, Build Quality, Innovation and Impact, Presentation and Process and all the sub-criteria related to them are determined by the academicians. Based on the criteria and data, the structured AHP hierarchy was derived in Figure 4. 


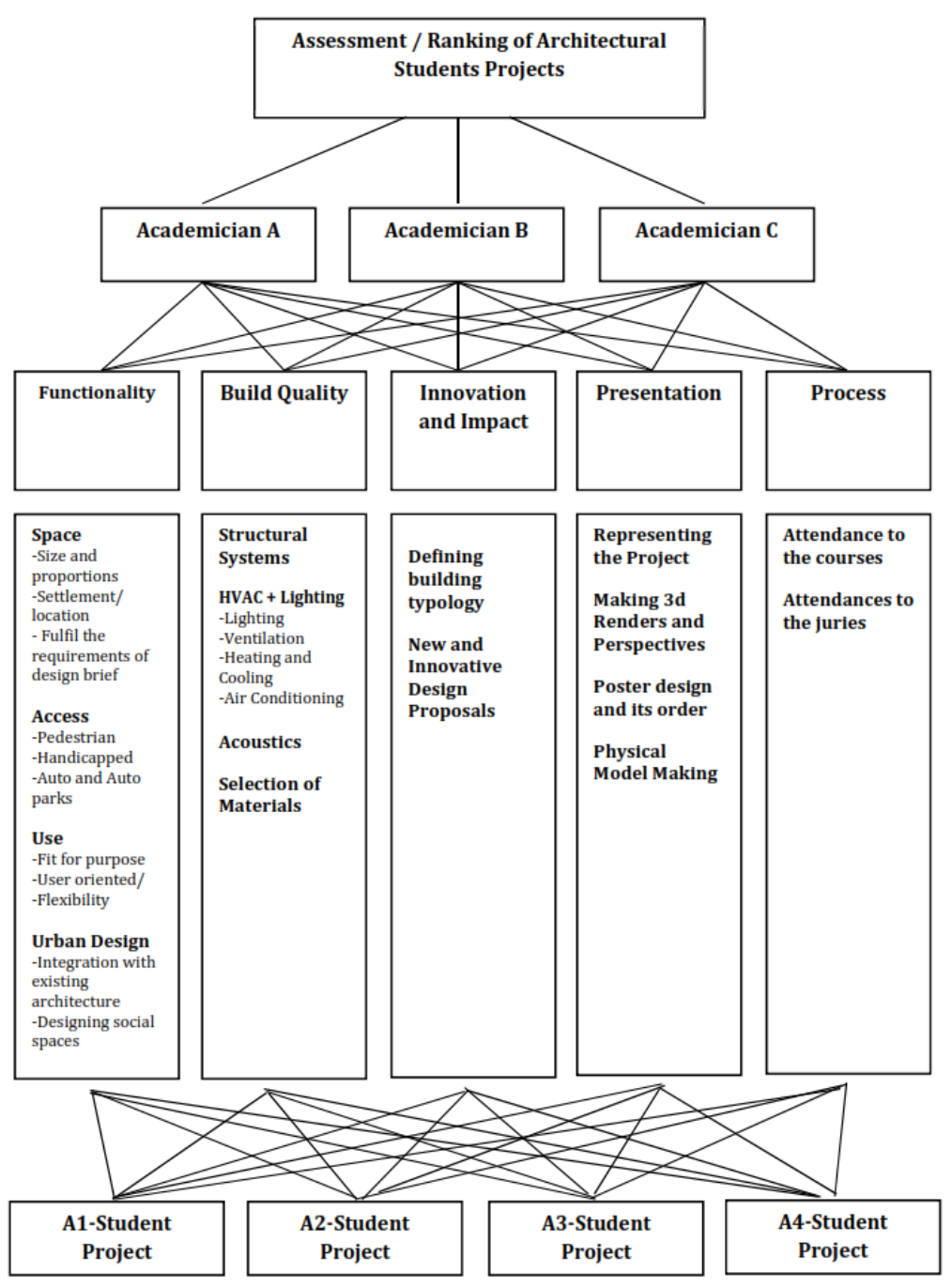

\section{Modelling}

Based on how the AHP hierarchy pairwise matrices are structured, a questionnaire was made ready for the decision makers using a total of 38 pairwise comparison matrices; 1 for the main criteria, 5 for the sub-criteria, 27 for the subsets of subcriteria, and 1 for the alternatives. The questionnaire was utilized by the decision makers individually. As part of the survey study; a sample questionnaire prepared for evaluation of the main criteria is provided in Table 5 .

The questionnaire was conducted with the contribution of each decision maker and their judgments were entered in to the Expert-choice software in which priority vectors with consistency ratios were calculated.
Figure 4. AHP based assessment hierarchy 
Table 5. Questionnaire sample for AHP assessment

\begin{tabular}{|l|c|c|c|c|c|c|c|c|c|c|c|c|c|c|c|c|c|r|}
\hline Functionality & 9 & 8 & 7 & 6 & 5 & 4 & 3 & 2 & 1 & 2 & 3 & 4 & 5 & 6 & 7 & 8 & 9 & Build Quality \\
\hline Functionality & 9 & 8 & 7 & 6 & 5 & 4 & 3 & 2 & 1 & 2 & 3 & 4 & 5 & 6 & 7 & 8 & 9 & $\begin{array}{r}\text { Innovation } \\
\text { and Impact }\end{array}$ \\
\hline Functionality & 9 & 8 & 7 & 6 & 5 & 4 & 3 & 2 & 1 & 2 & 3 & 4 & 5 & 6 & 7 & 8 & 9 & Presentation \\
\hline Functionality & 9 & 8 & 7 & 6 & 5 & 4 & 3 & 2 & 1 & 2 & 3 & 4 & 5 & 6 & 7 & 8 & 9 & Process \\
\hline Build Quality & 9 & 8 & 7 & 6 & 5 & 4 & 3 & 2 & 1 & 2 & 3 & 4 & 5 & 6 & 7 & 8 & 9 & and Impact \\
\hline Build Quality & 9 & 8 & 7 & 6 & 5 & 4 & 3 & 2 & 1 & 2 & 3 & 4 & 5 & 6 & 7 & 8 & 9 & Presentation \\
\hline Build Quality & 9 & 8 & 7 & 6 & 5 & 4 & 3 & 2 & 1 & 2 & 3 & 4 & 5 & 6 & 7 & 8 & 9 & Process \\
\hline Innovation & & & & & & & & & & & & & & & & & & Presentation \\
and Impact & 9 & 8 & 7 & 6 & 5 & 4 & 3 & 2 & 1 & 2 & 3 & 4 & 5 & 6 & 7 & 8 & 9 & Prevation \\
\hline Innovation & & & & & & & & & & & & & & & & & & \\
and Impact & 9 & 8 & 7 & 6 & 5 & 4 & 3 & 2 & 1 & 2 & 3 & 4 & 5 & 6 & 7 & 8 & 9 & Process \\
\hline Presentation & 9 & 8 & 7 & 6 & 5 & 4 & 3 & 2 & 1 & 2 & 3 & 4 & 5 & 6 & 7 & 8 & 9 & Process \\
\hline
\end{tabular}

\section{Findings}

Studio tutors were asked to review the projects individually according to the main and sub-criteria with expert-choice $(11.5$ academic version) software. With the software used, based on their individual and group evaluations of the academic group, priorities of criterion can be ranked according to the most widely disagreed or the closest agreed. Throughout the evaluation process, the academicians were simply identified as Academician1, Academician-2 and Academician-3 to maintain the objectivity of the research.

In the first stage, based on the main criteria, individual and combined priorities of three scholars were evaluated and graphically represented (figure 5). As indicated in Figure 5, according to evaluation of scholars, the degree of priority of the main criteria are shown as follows: Functionality $(\% 34,1)$ Innovation and Impact $(\% 33,9)$, Process $(\% 16,2)$, Build Quality $(\% 10,2)$, Presentation $(\% 0,56)$. The most important main criterion is the Functionality, while the Presentation is considered the least important. The total consistency rate was recorded as 0,04 and the results were deemed to be consistent since they were below 0,1 . 

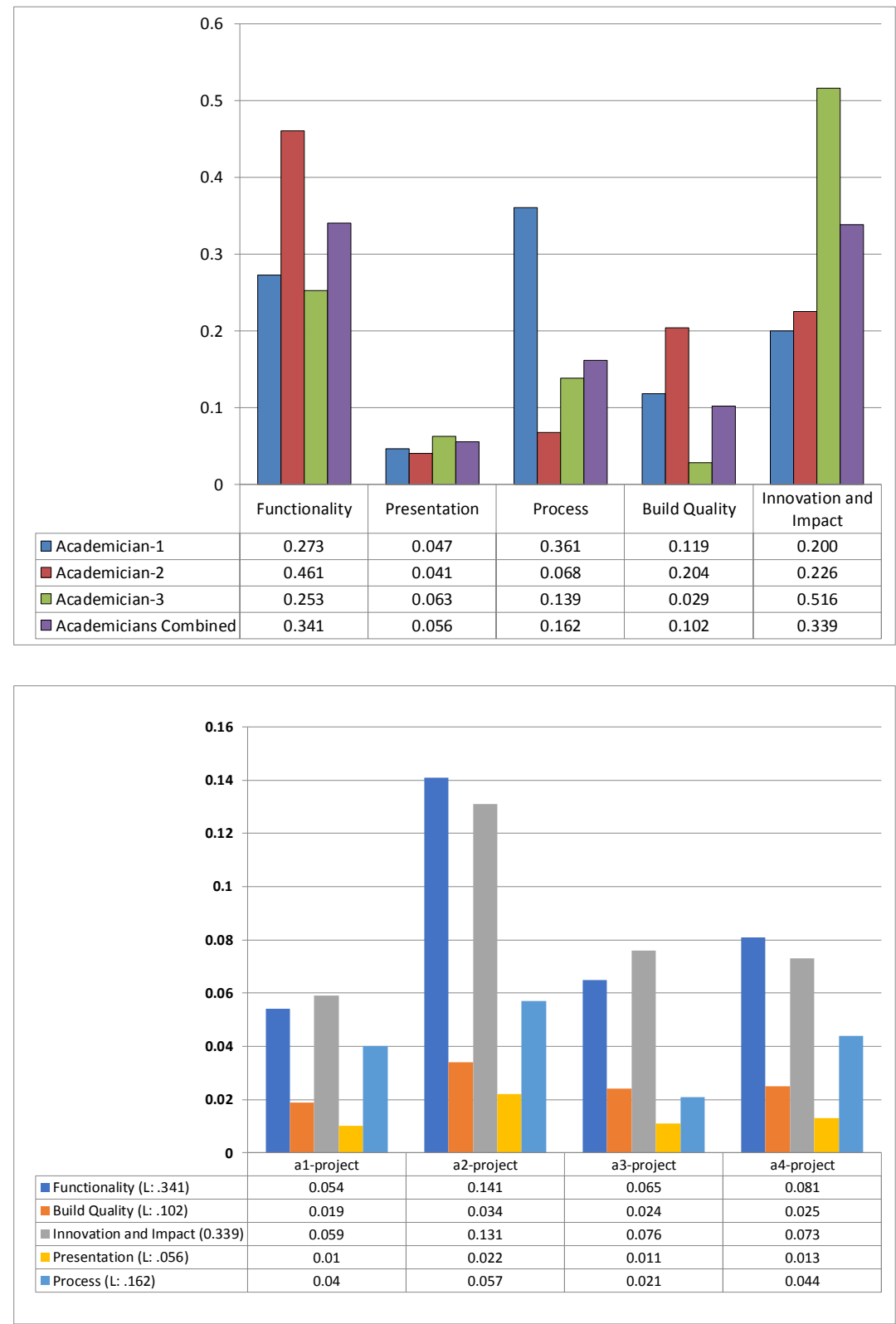

The most important main criterion for the academician- 1 was the Process, Functionality for the academician-2, and Innovation and Impact for the academician-3. According to the combined priorities of the scholars; it is seen that different percentages are obtained for the main criteria, Innovation and Impact, and Process, while the priority ratios for the main criterion for Presentation are close to each other (Figure 5). Figure 6 shows these percentages distributed to the student projects.
Figure 5. Priorities of academics for main criterion

Figure 6. Distribution of priorities of main criterion of academicians for project alternatives 
The percentages of the priorities of sub-criteria as well as the main criteria are shown in Figure 7. According to the combined evaluation of academicians; New and Innovative Design Proposals $(27,5 \%)$ Use $(13,2 \%)$ and Space $(12,8 \%)$ are the most noticeable sub-criterion (Figure 7). When the individual approaches of academicians are investigated, Attendance to Juries of Process, User Oriented Use and Fit for Purpose of Space appear to have distinct priority values.

Attendance to Juries, Fit for Purpose and the User Oriented appear to be the sub-criterion that the academicians have the most differences from the group combined priorities compared to the individual ones. Sub-criteria of New and Innovative Design Proposals is clearly above the group mean priority of the other sub-criteria (Figure 7).

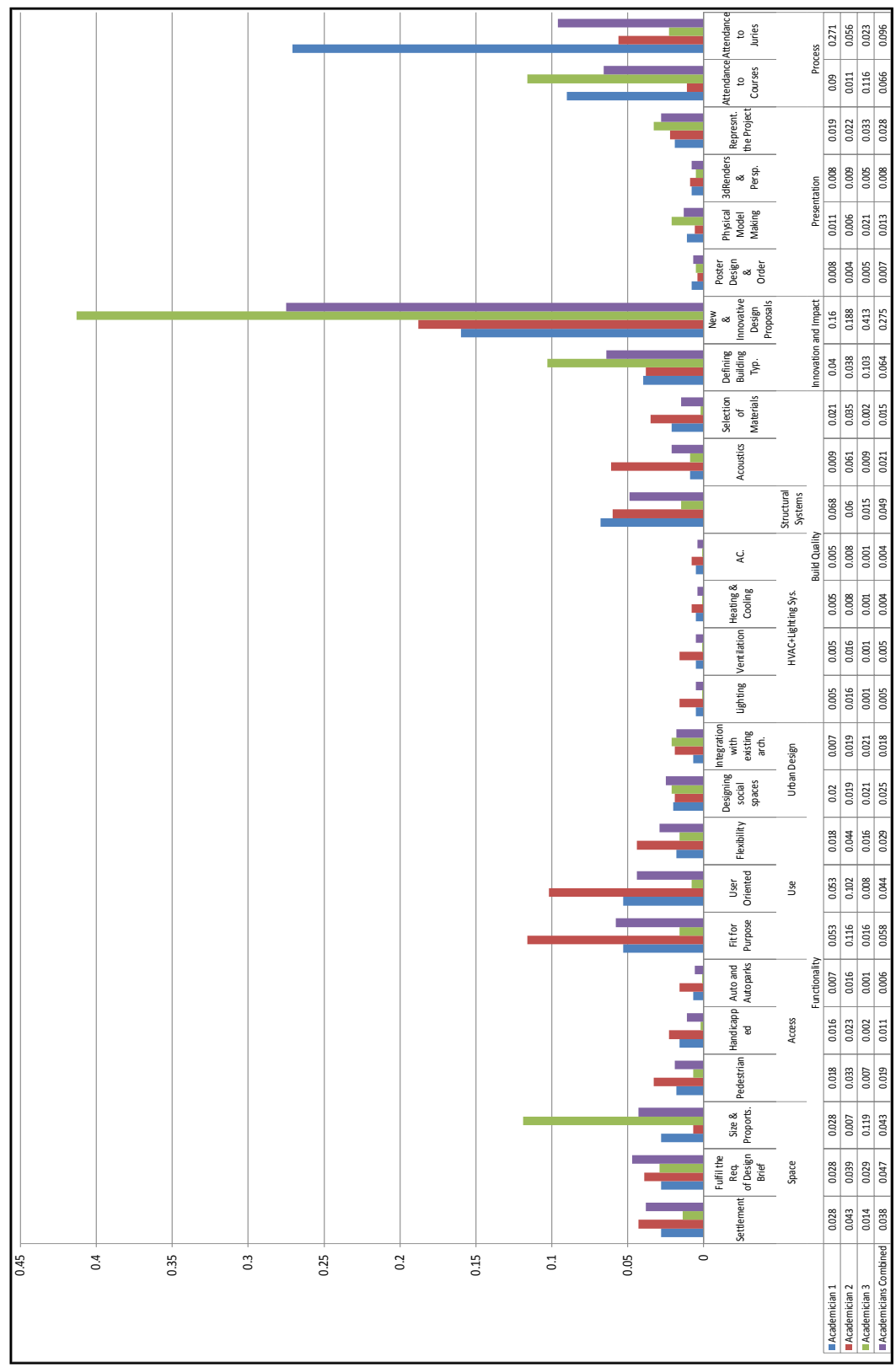


When the project alternatives were evaluated, considering the priority ratios in relation to the above mentioned main and sub criterion, the A-2 student project was found to be more successful than the other projects according to the priority order of the determined criteria (Figure 7). According to the evaluations of the academicians, the student projects are listed as A-2 (\%38,6), A-4 $(\% 23,6), A-3(\% 19,6)$ and A-1 $(\% 18,2)$ respectively (Figure 8). When individual assessments of all 3 academicians are analysed, it is seen that all the academicians with different priorities are putting forward the A- 2 project compared to the others.

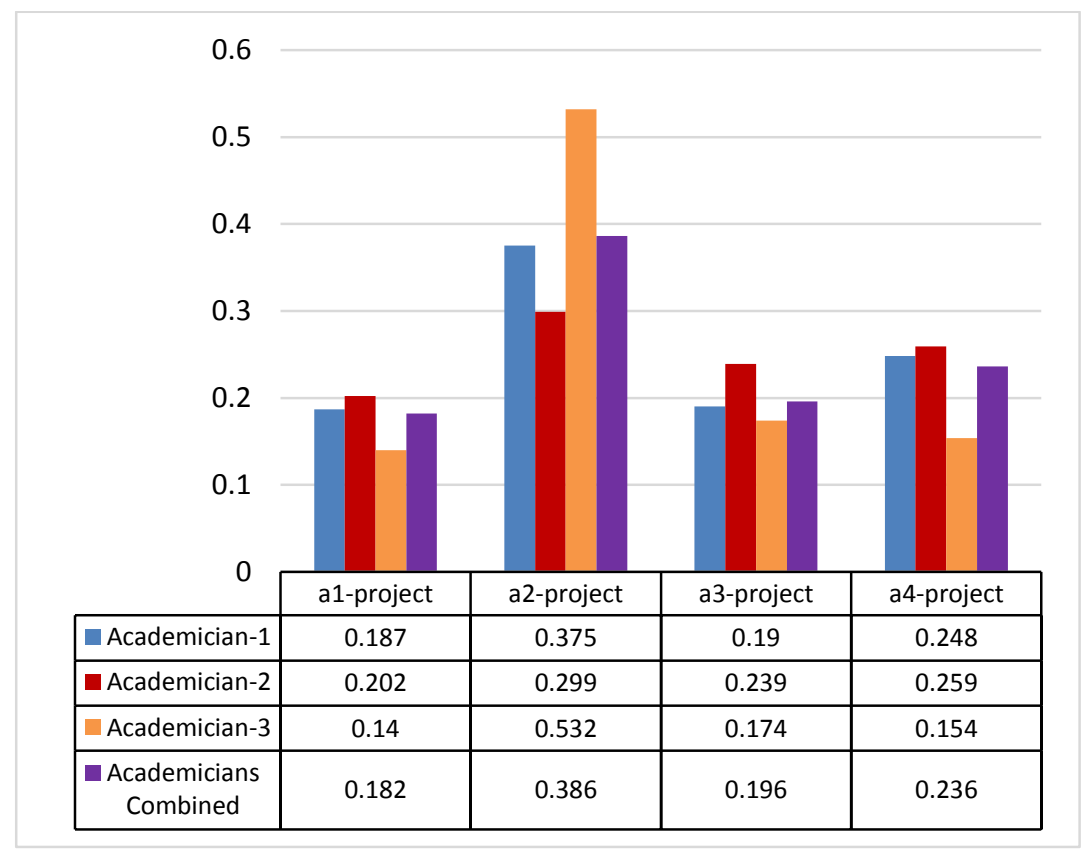

The priority table for each sub-criterion based on evaluation of student projects, is given in Figure 9. Based on sub-criteria assessments, it is observed that project proposals are limited with design of HVAC + Lighting systems, whereas, higher priority percentages of the sub-criterion of functionality reveals clear issues in the process of designing the projects.
Figure 8. Priorities of academicians for students' projects 
Figure 9. Assessment of students projects based on sub-criterion

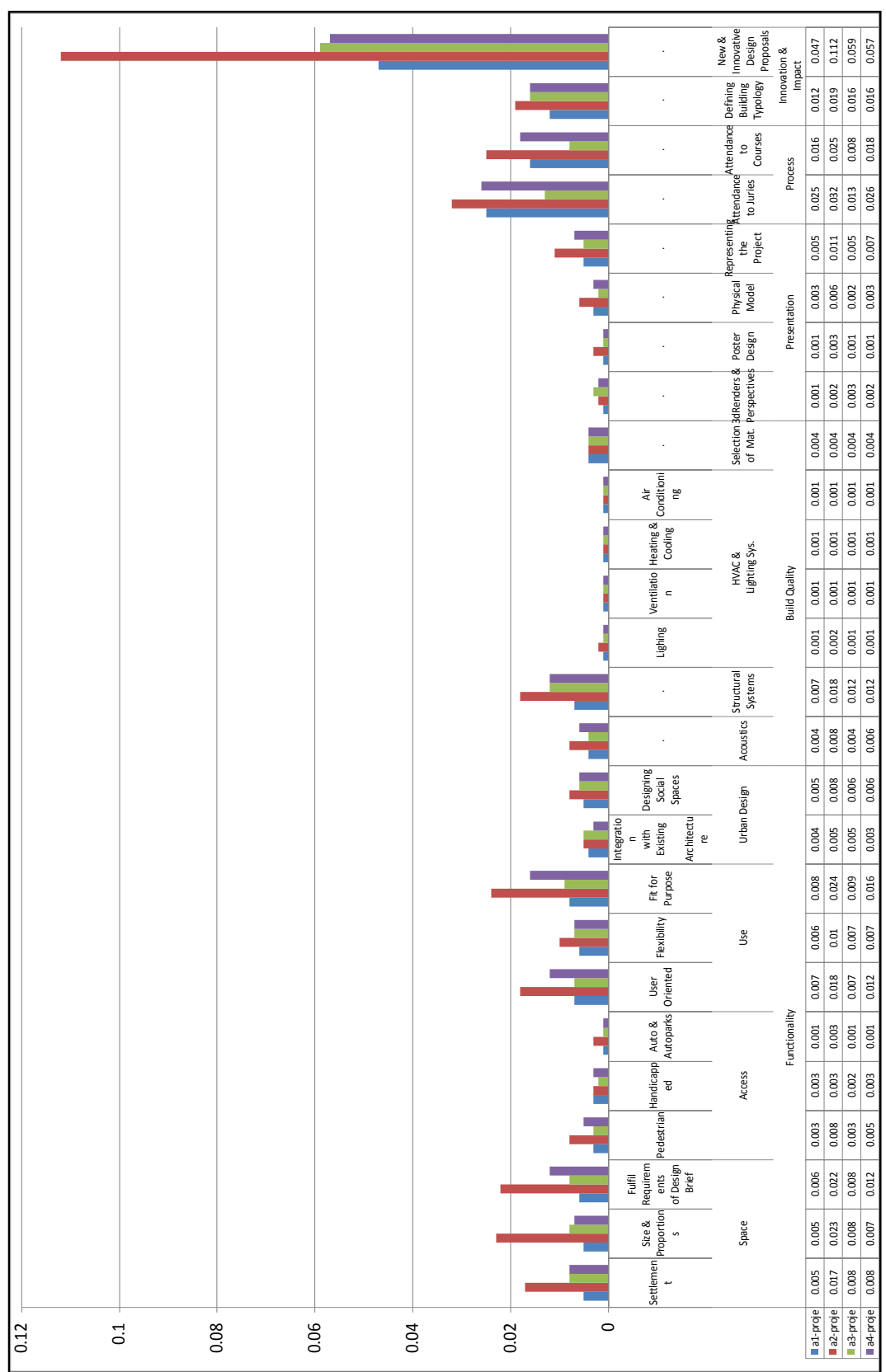

Based on the proposed AHP-based approach, comparative analyses of alternative projects with respect to defined criteria and sub-criteria can be evaluated in detail individually and as a group (Figure 9). Student project A2 lead other projects based on evaluations results of many of the sub-criterion. In addition, the project seemed to also lead in the sub criterion of Functionality such as, Fulfil Requirements of Design Brief, Fit for Purpose, User Oriented, Space Size and Proportions. The A2 project stood above other projects with a big difference on the sub-criteria of New and Innovative Design. In addition to this, according to the evaluations of the academicians, the decision thresholds of the project alternatives were determined in the context of the main criteria (Figure 10). Project A2 was deemed superior to other projects in 
terms of all main criteria. A4 project ranked second after A2 project, lead other projects based on main criteria except New and Innovative Design (Figure 10).

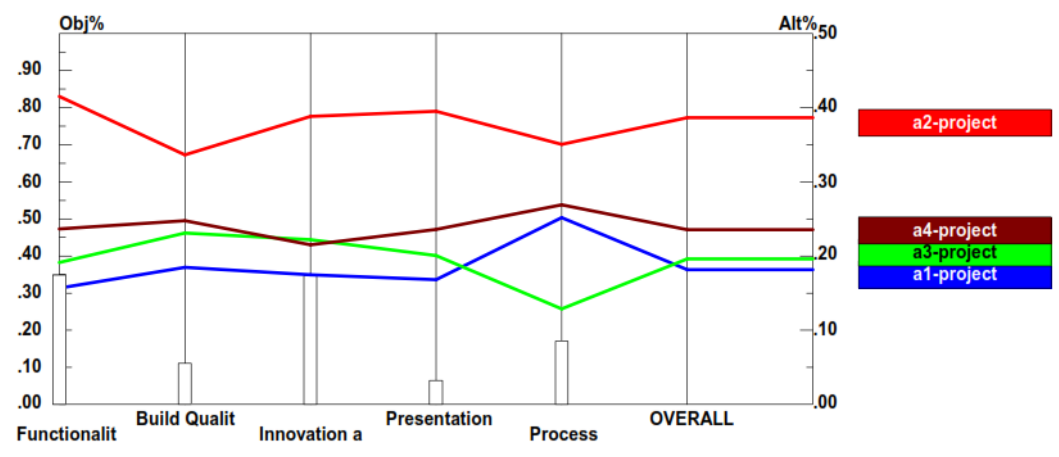

Objectives Names

\begin{tabular}{|ll|}
\hline Functionalit & Functionality \\
Build Qualit & Build Quality \\
Innovation a & Innovation and Impact \\
Presentation & Presentation \\
Process & Process \\
\hline
\end{tabular}

Priority percentages of main criterion of the projects were compared based on defined threshold levels. With the software used, what if scenarios were applied to follow the change in the priorities in selecting projects based on different threshold levels (Figure 11).
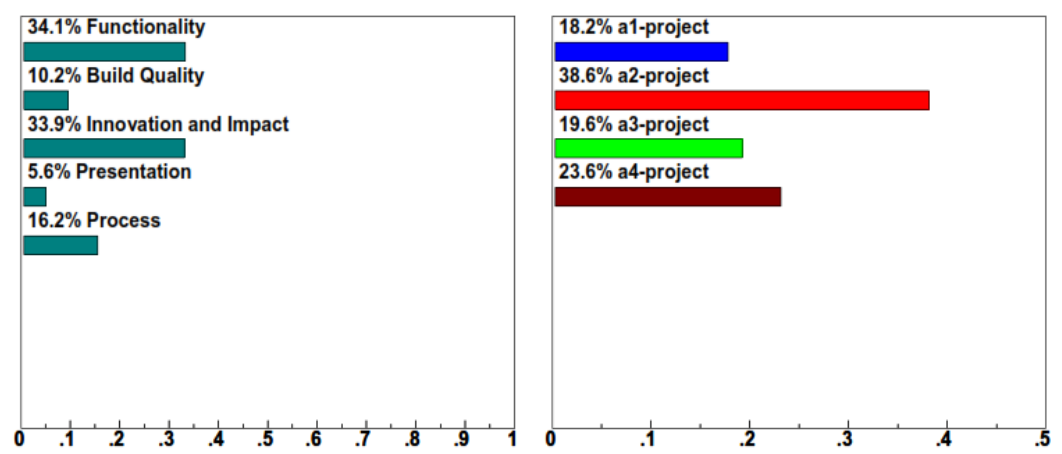

When desirable, the change in the ranking of the projects for different priority and status were examined by changing the weight ratios of the main criteria within the total (Figure 11). This approach can also make a one-to-one comparative analysis of alternative projects within the context of the main criteria according to participants' priorities. With the help of the software, alternative projects were evaluated against each other on five main criteria. Sample graphics of direct comparative evaluation of projects based on the main criterion are shown in Figure 12, Figure 13, Figure 14.
Figure 10. Threshold analysis of students projects based on main criterion

Figure 11. Assessment of students projects based on main criterion 
Figure 12. Comparison of student projects A2 vs A1 based on main criterion

Figure 13. Comparison of student projects A2 vs A3 based on main criterion

Figure 14. Comparison of student projects A2 vs A4 based on main criterion

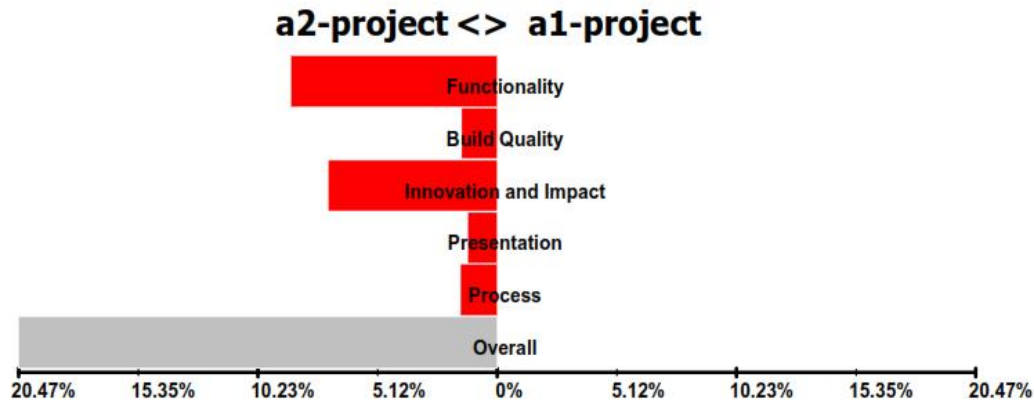

a2-project $<>$ a3-project

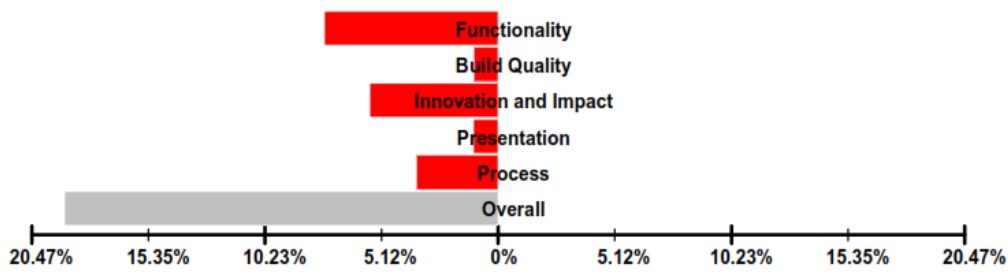

a2-project $<>$ a4-project

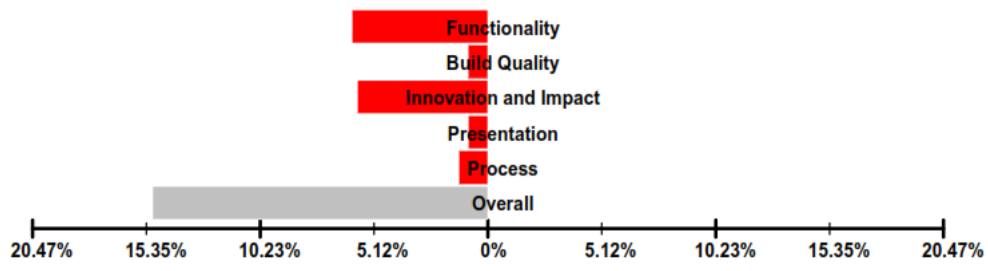

\section{DISCUSSION}

\section{Outcomes Of The Case Study}

The proposed AHP-based approach allows for modification or redefinition of criteria and sub-criteria for each project, offering comparative individual and group evaluation of project alternatives. The case study results reveal that participants' criteria priorities vary each other, however, the approach can identify these differences and reveal the threshold levels of change. This plays an important role in bringing about differences in evaluating the architectural projects where subjective evaluation is often made.

It is evident that the proposed AHP-based approach overlaps with the results of the traditional assessment. The results of the student project rankings in the traditional system are very similar to the student project rankings with the AHP-based approach. 
Competence levels, incomplete knowledge and underdeveloped abilities of the students assessed by the approach can be identified and consequently, concrete data can be presented for development of training/education strategies. Threshold levels can be quantified by sensitivity analysis. Accordingly, student projects that fall below the thresholds level, which can be defined as competence level, may possibly be deemed inadequate.

Besides its positive features, this approach, does not provide sufficient data for selection of alternatives based on criterion such as lighting, energy use, ventilation, heating, cooling and air conditioning which are rarely identified or included in the initial stages of design. In the development process of the projects, it was determined that these aspects were not studied or emphasized and therefore the approach could not produce distinctive information in these aspects of design.

\section{Feedback from The Contributing Academics and Arguments}

Based on the results obtained, participating academicians were asked their opinions about the outcomes of the applied approach. The results of the evaluation were reported as accurate, reliable and consistent. It should be acknowledged that this evaluation process differs from the existing/traditional one, and that the results were successful in terms of evaluating a limited number of student projects expressing individual and group considerations, but the evaluation process is likely to be tedious as the number of projects to be evaluated increases. It was particularly appreciated that, whether individual or group assessments, this approach can evaluate projects comparatively and can reveal both their positive and negative aspects. Obtaining the what if analyses was also found to be positive.

Regarding evaluation of the projects: determining the distinctions based on comparative evaluation and ranking the projects was found more valuable than the numerical based percentage evaluation results. It should be noted that there may be some margin of error with respect to the mathematical system in the total evaluation, so it may be useful to review some benchmarking results after the evaluation. It has been found beneficial for academicians to set their own evaluation priorities and to compare them with other academicians. In addition, validating the project results comparatively and concretely is also found to be useful in providing empirical support for the rankings.

In addition to the results of the project ranking success, overlap with the evaluation of the traditional system; numerical evaluation, comparative analysis and successful findings of the 
study, the proposed approach has been found to be innovative. The proposed method presents a high potential to be adaptive to the architectural design studio evaluation system.

\section{Discussion}

This study investigated the use of the AHP-based approach in student architectural project evaluations. Problems in the traditional evaluation system such as, not being able to clearly define the evaluation criteria, importance of the criterion relatively to each other for final decision, and to reach a common decision in the group evaluation process can be eliminated with this proposed approach. The ability of this approach to be used for individual and group evaluation, to redefine criteria and subcriteria for each different project work, to report results easily with the support of the software and the ability to make comparative evaluations of participants both common and different judgments on projects can be determined as outstanding advantages of the approach.

In the traditional methods of architectural evaluation, it is essential that assessors make assessments in terms of priorities and benchmarks that they deem applicable to the whole of the project design process. The outputs of the individual evaluation results are terms such as, good, bad, successful, unsuccessful or resulting grades based on certain numerical values. In group evaluations such as jury systems, it is not easy for each evaluation to obtain a common result. The competencies of jury members for expressing their priorities to the other jury members and the project designer during the evaluation process are also questions of debate. The most important outputs expected from an evaluation system are: to identify the strengths and weaknesses of the projects, determining the positive and negative aspects of the project comparatively with the other projects, to provide concrete, accountable, numerically comparable and consistent results. While traditional methods can be limited in this respect, the proposed AHP-based approach emerges as an evaluation approach that can cover the aforementioned outputs and provide the broadest possible feedback. Contribution to these discussions were made by comparing the results of the evaluation using the traditional system to the evaluation with the AHP-based approach. It is evident that ranking of the projects in both systems are the very similar, however information from analysis that the AHP-based approach provided from the reporting and evaluation process yielded useful feedback. The added value of this approach can be quantified as: i)adaptability, ii)the ability to add or remove more evaluators, iii) the ease of sub clustering among the 
evaluators, iv)ability to restructure the assessment hierarchy based on project typology and evaluators determination.

While the proposed approach successfully assesses a limited number of projects, as the number of projects increases, it may be necessary for the evaluators to spend more time and energy, which will inevitably become tedious and mentally taxing. In this context, the AHP-based approach allows limited number of projects to be evaluated simultaneously. If the number of projects to be evaluated is high, it is likely that a singular/separated evaluation of each project will be a more accurate approach depending on the upper and lower threshold levels that can be defined by the evaluators. Evaluation based on these threshold levels for each project can also be visually reported with graphics. Evaluation taking into account of sensitivity analysis is also possible with the software used in this study or with other software that can be used for AHP evaluation. In addition to all this, what if analysis can also be extended to cover all criteria and sub-criteria.

Considering the limited knowledge of mathematics and AHP of the participants, it is deemed useful to integrate and adapt the existing or different software of AHP for assessment processes. It is recommended to transfer numerical values to evaluation analyses with graphical comparison tables for clear reporting of the results. The AHP-based approach will allow these expectations to be met, including the accuracy, reliability, consistency and transparency that any valid assessment requires.

Since they have been educated in the traditional assessment processes and are accustomed to being evaluated and to evaluate with traditional systems for years; the architectural academic community may not easily adopt this approach and replace it with current assessment systems in the short term. It should also be noted that those who wish to apply this approach may have to go through preliminary education and training due to the mathematical base and systems used.

It may be considered that the evaluation of AHP in the linear direction may cause problems in the architectural evaluation process since architectural design is not regarded as a simple sum of values that can be evaluated in a linear direction with equal proportion. Considering this, the AHP-based approach should be used for evaluation and ranking, based on criteria, to establish project superiority and incompleteness compared to other alternatives, rather than using priority percentages for comparison. With this study, it is evident that the projects ranked 
with this approach (comparative analysis-based) can provide more descriptive results than those ranked in the traditional system which is based on numerical values.

\section{CONCLUSION}

One observation is that the applied AHP-based approach overlaps with the evaluation results of the traditional system based on ranking project alternatives according to their success. In this sense it was supported with case the study that this approach is suitable for ranking project alternatives and facilitates both individual and group evaluations and can present the results quickly and reliably which was also confirmed by academicians participating in the evaluation process. Moreover, the approach has also been found to be successful in areas in which traditional assessment systems are limited such as establishing clear definition of criteria and sub-criteria through the evaluation process, evaluation of alternative projects accordingly, determination of priorities of evaluation criteria, comparative analysis and consistency control.

The implementation of this approach also allows for evaluating project alternatives as pass or fail/successful or unsuccessful based on the threshold levels determined by tutors. Additionally, it is clear that the approach has potential to be developed not only for evaluation in architectural education but also for architectural project competitions. Moreover, the approach can be adapted to be used as a checklist for checking compliances with the standards determined by the regulated outcomes. Although not implemented within this case study, numerical or percentage threshold levels can be assigned to the evaluation criteria requirements of the projects to establish competency levels. In all these processes, comparative analysis of the projects can be done in terms of all defined criteria and sub-criteria. In addition, with the software used in this approach, it is possible to transfer outputs of what if analyses with graphics to compare the advantages/disadvantages of project alternatives.

This approach identifies the underlying fundamental dynamics of the participants in the group decision making process and presents useful analyses to establish a consensus. Beyond this, the approach has potential to be used to identify projects that fall below the threshold levels set, to identify missing fundamentals in the education of students, and to generate feedback for the education system. In addition to the many benefits of the proposed AHP-based approach for architectural education, there is also the negative issue of an increased length of evaluation time that may arise as the number of students assessed increases, and 
the tediousness of the task. Based on all these findings, however, it is concluded that the AHP-based approach has a high potential for both increased competence and development for evaluating architectural projects, along with their alternatives, especially within architectural design education and architectural design competitions.

\section{SYMBOLS}

$\begin{array}{ll}\lambda \max & : \text { Eigen Value of AHP Decision Matrix } \\ \text { A } & : \text { Decision Matrix } \\ \text { AHP } & : \text { Analytic Hierarchy Process } \\ \text { CI } & : \text { Consistency Index } \\ \text { CR } & : \text { Consistency Ratio } \\ \text { RI } & : \text { Random Consistency Index } \\ \text { w } & : \text { Eigen Vector }\end{array}$

\section{Acknowledgment}

I would like to thank the following scholars: Inst. Oktay Veral, Inst. Yurdanur Sepkin and Inst. Aysel Veral who contributed to the execution of this work and for their interest and support. I would also like to thank the students of Çankaya University Architecture Department who graduated in the 2014-2015 academic year whose projects were used for this study. And finally, I would like to thank Prof. Dr. Y. Illker Topçu for his suggestions and contributions towards finalizing this research.

\section{REFERENCES}

Adamović, P., Maja, C.D., Nahod, M. (2008). Expert Choice Model For Choosing Appropriate Trenchless Method For Pipe Laying. Journal of Expert Choice, p. 1-12.

Akadiri, P.O., Olomolaiye P.O., Chinyio E.A. (2013). Multi-Criteria Evaluation Model For The Selection Of Sustainable Materials For Building Projects. Automation in Construction, 30, p. 113-125.

Aksakal, E., Dagdeviren, M., (2015). Talent Management Based Personnel Assignment Model And Solution Proposal. Journal of the Faculty of Engineering and Architecture of Gazi University, 30(2), p. 249-262.

Alagbe, O. A., Oluwatayo, A. A., Aderonmu, P. A., \& Alalade, G. M. (2015). Difference in Grading Parameters in Architectural Schools And its Impact On the Competency Rating of Future Professionals. Frontiers of Architectural Research, 4(3), p. 230-236.

Alessio, I., Ashraf, L. (2009). Analytic Hierarchy Process and Expert Choice: Benefits and Limitations. OR Insight, 22(4), p. 201-220. 
Al-Harbi, K.M.A.S. (2001). Application Of The AHP in Project Management. International Journal of Project Management, 19(1), p. 19-27.

Ali, H.H., Al Nsairat, S.F. (2009). Developing a Green Building Assessment Tool For Developing Countries-Case of Jordan. Building and Environment, 44(5), p. 1053-1064.

Aminbakhsh, S., Gündüz, M., Sönmez, R., (2013). Safety Risk Assessment Using Analytic Hierarchy Process (AHP) During Planning and Budgeting Construction Projects. Journal of Safety Research, 46, p. 99-105.

Arroyo, P., Tommelein, I. D., \& Ballard, G. (2014). Comparing AHP and CBA as decision methods to resolve the choosing problem in detailed design. Journal of construction engineering and management, 141(1), 04014063.

Bitarafan, M., Hosseini, S. B., Abazarlou, S., Mahmoudzadeh, A. (2015). Selecting the optimal composition of architectural forms from the perspective of civil defense using AHP and IHWP methods, Architectural Engineering and Design Management, 11:2, 137-148,

Çıkış, Ş., Çil, E. (2009). Problematization Of Assessment İn The Architectural Design Education: First Year As A Case Study. In Procedia - Social and Behavioral Sciences, Volume 1, Issue 1, p. 2103-2110.

Crooks, T. J., Kane, M. T., Cohen, A. S. (1996). Threats to the Valid Use of Assessments. Assessment in Education: Principles. Policy \& Practice, 3(3), p.265-286.

Davis, D. (1997). Design As A Process The Project Development Process. Annual Conference, Milwaukee, Wisconsin.

Dickson, M. (2004). Achieving Quality In Building Design By Intention, Designing Better Buildings. Spon Press, London, UK.

Gandhi, S., Mangla, S.K., Kumar, P., Kumar, D. (2016). A Combined Approach Using Ahp And Dematel For Evaluating Success Factors in Implementation Of Green Supply Chain Management in Indian Manufacturing Industries. International Journal of Logistics Research and Applications, 19(6), p. 537-561.

Harputlugil T., Gültekin, A.T., Prins, M., Topcu, Y.I., (2014). Architectural Design Quality Assessment Based On Analytic Hierarchy Process: A Case Study. METU Journal of the Faculty of Architecture, 31(2), p.139-161.

Harputlugil, T., Prins, M., Gultekin, A.T., Topçu, İ. (2011). Conceptual Framework For Potential Implementations Of Multi Criteria Decision Making (MCDM) Methods For Design Quality Assessment. CIB International Conference of Management and Innovation for Sustainable Build Environment, Amsterdam, The Netherlands.

Hassanpour, B., Ani, A. I. C., (2015). Transparent Assessment Model In Architecture Design Studio: Eastern Mediterranean University As Case Study. Open House International , 40:2, p.37-43.

Heravi, G., Fathi, M., Faeghi, S. (2017). Multi-Criteria Group Decision-Making Method For Optimal Selection of Sustainable İndustrial Building Options Focused On 
Petrochemical Projects. Journal of Cleaner Production, 142, p. 2999-3013.

Hickman, R. (2007). Whippet-Fancying and Other Vices: ReEvaluating Assessment in Art and Design. The Problem of Assessment in Art and Design. Chicago: Intellect, p.77-88.

Jato-Espino, D., Castillo-Lopez, E., Rodriguez-Hernandez J., Canteras-Jordana J.C. (2014). A Review Of Application Of Multi-Criteria Decision Making Methods in Construction. Automation in Construction, 45, p. 151-162.

Kalaycı, P. D. (2016). Etkileşimden Bütünleşmeye- Bir mimari Tasarım Stüdyosu Pratiğinin Anatomisi, Nobel Yayıncllık, Ankara, Türkiye.

Kuruüzüm, A., \& Atsan, N. (2001). Analitik Hiyerarşi Yöntemi Ve İşletmecilik Alanındaki Uygulamaları. Akdeniz University Faculty of Economics \& Administrative Sciences Faculty Journal, 1(1), p. 83-105.

Lai, Y.T., Wang, W.C., Wang, H.H. (2008). AHP-And SimulationBased Budget Determination Procedure For Public Building Construction Projects", Automation in Construction, 17(5), p. 623-632.

Lee, G.K., Chan, E.H. (2008). The Analytic Hierarchy Process (AHP) Approach For Assesment of Urban Renewal Proposals. Social Indicators Research, 89(1), p. 155-168.

Markelj, J., Kitek Kuzman, M., Grošelj, P., Zbašnik-Senegačnik, M. (2014). A Simplified Method For Evaluating Building Sustainability in The Early Design Phase for Architects. Sustainability, 6(12), p. 8775-8795.

Mela, K., Tiainen, T., Heinisuo, M. (2012). Comparative Study Of Multiple Criteria Decision Making Methods For Building Design. Advanced Engineering Informatics, 26(4), p. 716726.

Mulliner, E., Malys, N., Maliene, V. (2016). Comparative Analysis Of MCDM Methods For The Assessment Of Sustainable Housing Affordability. Omega, 59, p.146-156.

Nahid, M., Gholam, R.A. (2010). Railway Station Site Selection Using Analytical Hierarchy Process And Data Envelopment Analysis. Computers \& Industrial Engineering, 59(1), p. 107-114.

Nazidizaji, S., Tomé, A., Regateiro, F. (2014). Search For Design Intelligence: A Field Study On The Role Of Emotional İntelligence In Architectural Design Studios. In Frontiers of Architectural Research, Volume 3, Issue 4, p.413-423.

Omkarprasad, S.V., Sushil, K. (2006). Analytic Hierarchy Process: An Overview of Applications. European Journal of Operational Research, 169 (1), p. 1-29.

Özcan, T., Çelebi, N., Esnaf, Ş., (2011). Comparative Analysis of Multi-Criteria Decision Making Methodologies and Implementation of a Warehouse Location Selection Problem. Expert Systems with Applications, 38(8), p. 9773-9779.

Palabiyik, S., Colakoglu, B. (2012). Mimari Tasarim Surecinde Son Urunun Degerlendirilmesi: Bir Bulanik Karar Verme Modeli. Megaron Architecture, 7(3), p.191-207. 
Pandav, C., Sachin, K.C., Kiran, M.J, Basanta, M.S., Prabin, K. (2016). Application of an Analytic Hierarchy Process (AHP) in the GIS Interface For Suitable Fire Site Selection: A Case Study from Kathmandu Metropolitan City, Nepal. SocioEconomic Planning Sciences, 53, p. 60-71.

Ribeiro, R. A., Moreira, A. M., Van, den Broek P., Pimentel, A. (2011). Hybrid Assessment Method For Software Engineering Decisions. Decision Support Systems, 51(1), p. 208-219.

Saaty, T.L. (1980). The Analytic Hierarchy Process, McGraw-Hill International, New York, U.S.A.

Saaty, T. L. (1986). Axiomatic Foundation of The Analytic Hierarchy Process. Management Science, 32(7), p. 841855.

Saaty, T.L. (1990). The Analytic Hierarchy Process, RWS Publications, Pittsburgh, U.S.A.

Saaty, T. L. (1994). Highlights and Critical Points in The Theory And Application Of The Analytic Hierarchy Process. European Journal of Operational Research, 74(3), p. 426447.

Sebastian, R. (2007). Managing Collaborative Design. Eburon, Delft, The Netherlands.

Si, J., Marjanovic-Halburd, L., Nasiri, F., Bell, S. (2016). Assessment Of Building-Integrated Green Technologies: A Review And Case Study On Applications Of Multi-Criteria Decision Making (MCDM) Method. Sustainable Cities and Society, 27, p.106-115.

Simon, H. A. (1969). The Sciences of the Artificial. M.I.T. Press, Cambridge, U.S.A.

Timor, M. (2011). Analitik Hiyerarşi Prosesi. Türkmen Kitabevi, Türkiye.

Triantaphyllou, E. (2000). Multi Criteria Decision Making Methods: A Comparative Study. Kluwer Academic Publisher, London, UK.

Triantaphyllou, E., Mann, S.H. (1995). Using The Analytic Hierarchy Process For Decision Making in Engineering Applications: Some Challenges. International Journal of Industrial Engineering: Applications and Practices, 2(1), p. 35-44.

Tsai, W.H., Lin, S.J., Lee, Y.F., Chang, Y.C., Hsu, J.L. (2013). Construction Method Selection For Green Building Projects To Improve Environmental Sustainability By Using An MCDM Approach. Journal of Environmental Planning and Management, 56(10), p. 1487-1510.

Utaberta, N., Hassanpour, B., Bahar, M. A., \& Ani, A. I. C. (2013). A Comprehensive Learning of Architecture Education: Understanding Critique Session As Learning Process And Criteria-Based Assessment in The Architecture Design Studio. Procedia-Social and Behavioral Sciences, 102, p. 21-32.

Webster, H. (2006). Power, Freedom and Resistance: Excavating the Design Jury. Journal of Art and Design Education, vol.25, no.3, p. 286-296. 
Williams, A., Ostwald M., Askland H.H. (2010). Assessing Creativity in the Context of Architectural Design Education. Proceedings DRS2010, Montreal, Canada.

\section{Resume}

Timuçin Harputlugil, born in 1975, had his bachelor, master and PhD titles from department of architecture of Gazi University between years 1994-2012. He is recently working as an Assistant Professor at the Department of Architecture of Faculty of Architecture of Çankaya University. Beside his academic career, he was involved in design and construction process of several buildings. He was a guest researcher in Technical University of Eindhoven(TU/e) in 2005 and Delft University of Technology in 2010-2011 for six months which was granted by Tubitak. He has several articles, international and national conference papers and a mention prize of a national architectural competition. He is scholarly interested in Building Technologies, Architectural Design Quality, Multi Criteria Decision Making Methods in Design and Energy Efficient Design. He is married and father of two. 